\title{
Cololejeuneae (Lejeuneaceae, Hepaticae) na Estação Científica Ferreira Penna, Melgaço, PA, Brasil
}

\author{
Anna Luiza Ilkiu-Borges ${ }^{1,2}$ e Regina Célia Lobato Lisboa ${ }^{1}$
}

Recebido em 25/02/2003. Aceito em 02/06/2004

\begin{abstract}
RESUMO - (Cololejeuneae (Lejeuneaceae, Hepaticae) na Estação Científica Ferreira Penna, Melgaço, PA, Brasil). Foi realizado inventário de Lejeuneaceae (Hepaticae) na Estação Científica Ferreira Penna, município de Melgaço, Pará, onde foi observada a ocorrência de oito espécies de Cololejeuneae (Spruce) Schiffner. Destacaram-se Aphanolejeunea truncatifolia Horik., Cololejeunea obliqua (Nees \& Mont.) S.W. Arnell e C. surinamensis Tixier como novas ocorrências para o Estado. Aphanolejeunea contractiloba (A. Evans) R.M. Schust., A. gracilis Jov.-Ast e A. winkleri Morales \& A. Lucking são novas ocorrências para o Brasil. Todas as espécies são descritas e ilustradas e é apresentada chave artificial para a identificação das mesmas, assim como comentários adicionais.
\end{abstract}

Palavras-chave: Cololejeuneae, Lejeuneaceae, hepáticas, brioflora, Pará

ABSTRACT - (Cololejeuneae (Lejeuneaceae, Hepaticae) in the Ferreira Penna Research Station, Melgaço, Pará State, Brazil). A survey of the Lejeuneaceae (Hepaticae) family was performed at Ferreira Penna Research Station, Melgaço municipality, Pará State, where was observed eight species of Cololejeuneae. The species Aphanolejeunea truncatifolia Horik., Cololejeunea obliqua (Nees \& Mont.) S.W. Arnell and C. surinamensis Tixier are new records for the State, while A. contractiloba (A. Evans) R.M. Schust., A. gracilis Jov.-Ast and A. winkleri Morales \& A. Lucking are new records to Brazil. The species are described and illustrated and an artificial key is presented to identifying them, as well as additional comments.

Key words: Cololejeuneae, Lejeuneaceae, liverworts, bryoflora, Pará State

\section{Introdução}

Lejeuneaceae é uma das maiores famílias de hepáticas na Amazonia. Yano (1984a; 1989; 1995) reportou 212 espécies, distribuídas em 43 gêneros. Somente no Estado do Pará encontram-se 69 espécies, distribuídas em 31 gêneros. Em levantamento realizado no município de Belém (Lisboa \& Ilkiu-Borges 1995), uma área que corresponde a 0,06\% do Estado do Pará, foram identificadas 37 espécies de Lejeuneaceae, ou seja, 55\% do total encontrado no Estado. Das 37 espécies, 13 são novas citações para o Pará e três são novas citações para o Brasil. Portanto, verifica-se que ainda falta muito a ser inventariado e estudado, ampliando o conhecimento sobre essa família e sua diversidade.

O objetivo deste trabalho é ampliar a distribuição geográfica e verificar a diversidade de espécies da tribo Cololejeuneae e contribuir para o conhecimento da família Lejeuneaceae na Estação Científica Ferreira Penna, trazendo novos dados para o Estado do Pará.

\section{Material e métodos}

O material estudado foi coletado na Estação Científica Ferreira Penna (ECFPn), localizada na Floresta Nacional de Caxiuanã, município de Melgaço, Pará, Brasil.

A coleta de material seguiu as técnicas adotadas em Yano (1984b) e Lisboa (1993), e as espécies foram classificadas de acordo com os tipos de substratos onde foram coletadas: corticícola (tronco vivo), epíxila (árvore morta e epífila) e epífila (folha viva).

Para a identificação foi utilizada bibliografia especializada e/ou realizada a comparação com espécimes identificados por especialistas. Algumas amostras foram identificadas diretamente pelo Dr. Tamas Pócs, com o envio de material para o Ezsterhazy Teachers’ College (Hungria), e pela Dra. Andrea Bernecker, em comunicação pessoal (1998) no Instituto Albrecht-von-Haller, Göttingen (Alemanha).

As descrições das espécies foram baseadas no material encontrado e, portanto, nem todas incluem a

\footnotetext{
1 Museu Paraense Emílio Goeldi, Coordenação de Botânica, C. Postal 399, CEP 66040-170, Belém, PA, Brasil (regina@museu-goeldi.br)

2 Autor para correspondência: ilkiuborges@yahoo.com.br
} 
descrição das estruturas reprodutivas, por estarem ausentes no material coletado.

As exsicatas foram depositadas no Herbário “João Murça Pires” (MG), do Museu Paraense Emílio Goeldi.

\section{Resultados e discussão}

Foram encontradas oito espécies, distribuídas em quatro gêneros da tribo Cololejeuneae, na Estação Científica Ferreira Penna (ECFPn). A lista de espécies, apresentada a seguir, está organizada de forma sistemática, segundo Gradstein et al. (2001).

Lejeuneaceceae Casares-Gil

Tribo Cololejeuneae R.M. Schuster

I. Aphanolejeunea A.Evans

Aphanolejeunea contractiloba (A.Evans)

R.M.Schust.

Aphanolejeunea gracilis Jov.-Ast

Aphanolejeunea truncatifolia Horik.

Aphanolejeunea winkleri Morales \& A.Lücking

II. Cololejeunea (Spruce) Schiffn.

Cololejeunea obliqua (Nees \& Mont.) Schiffn.

Cololejeunea surinamensis Tixier

III. Colura (Dum.) Dum.

Colura tortifolia (Nees \& Mont.) Steph.

IV. Diplasiolejeunea (Spruce) Schiffn.

Diplasiolejeunea brunnea Steph.

Tribo Cololejeuneae R.M. Schust., Hep. Anthoc. North Amer., 4: 1229. 1980.

Gametófitos geralmente pequenos, verde-pálidos, algumas vezes verde-escuros, raramente castanhos. Ramificações vegetativas do tipo-Lejeunea, raramente do tipo Aphanolejeunea (em Aphanolejeunea spp.). Caulídios muito delgados, com merófito ventral de 1-2 células de largura. Linha de inserção do filídio muito curta. Lóbulo com papila hialina marginal no ápice. Ocelos presentes ou ausentes. Anfigastros quando presentes, um por filídio, na maioria bífidos ou ausentes (no lugar, aparece um tufo de rizóides por filídio). Androécio em ramos curtos; bractéolas masculinas restritas à base da espiga, ocasionalmente distribuída por toda a espiga; brácteas masculinas com lóbulos grandes, hipostáticos. Periantos com 0-2 quilhas ventrais. Seta articulada apenas 12 fileiras externas de células e 4 internas. Valvas das cápsulas sub-eretas após a deiscência, pálidas, células da camada externa com paredes celulares finas, células da camada interna com pequenos espessamentos nodulosos nas paredes celulares. Poucos elatérios, extremidades superiores presas somente às margens das valvas, rudimentarmente espiralados, pálidos. Esporos longo-retangulares, sem rosetas. Reprodução vegetativa por meio de gemas discóides (Schuster 1980; Gradstein et al. 2001).

\section{Chave artificial para os gêneros da tribo} Cololejeuneae

1. Anfigastros presentes .......................................... 2

1. Anfigastros ausentes ............................................ 3

2. Filídios em forma de saco; ocelos ausentes III. Colura

2. Filídios planos, oblongo-orbiculares; ocelos presentes .............IV. Diplasiolejeunea

3. Plantas com 0,18-0,7mm larg.; filídios dimórficos; lóbulos desenvolvidos ou reduzidos a 1-3 células; borda hialina sempre ausente I. Aphanolejeunea

3. Plantas com 1,3-2,7mm larg.; filídios não dimórficos; lóbulos sempre desenvolvidos; borda hialina de células mortas às vezes presente II. Cololejeunea

\section{Aphanolejeunea A. Evans}

Segundo Gradstein et al. (2001), este gênero é pantropical e apresenta cerca de 20 a 30 espécies em baixas elevações na América Tropical. Na ECFPn foram encontradas quatro espécies deste gênero.

\section{Chave artificial as espécies de Aphanolejeunea}

1. Células do filídio com superfície dorsal cônica, 1 papila central 1. A. contractiloba

1. Células do filídio com superfície dorsal lisa, sem papila (às vezes mamilosas na margem).

2. Filídios com uma reentrância na junção do lóbulo e lobo, marcada por duas células protuberantes na superfície ventral do lóbulo 4. A. winkleri

2. Filídios sem reentrância na junção do lóbulo e lobo, células protuberantes na superfície ventral do lóbulo ausentes 
3. Em lóbulos desenvolvidos, primeiro dente unicelular, segundo dente ausente 2. A. gracilis

3. Em lóbulos desenvolvidos, primeiro dente de duas células compr., segundo dente unicelular (às vezes obsoleto) 3. A. truncatifolia

1. Aphanolejeunea contractiloba (A. Evans) R.M. Schust., Hepat. Anthocer. N. Amer., 4: 1314. 1980.

Cololejeunea contractiloba A. Evans, Amer. J. Bot., 5: 131. 1918. Tipo. EUA. Florida, Sanford, 28/IX/1915, S. Rapp.

Fig. 1.

Gametófitos verde-pálidos a amarelo-esverdeados, 1-2mm compr. × 0,18-0,25mm larg. Caulídio em secção transversal, 5 células epidérmicas circundando 1 célula medular de tamanho um pouco menor; merófito ventral de 1 célula de largura. Filídios distantes a contíguos, dispostos obliquamente, planos a côncavos, dimórficos; filídios com lóbulos reduzidos, lanceolados, 150-170 $\mu \mathrm{m}$ compr. $\times 60-70 \mu \mathrm{m}$ larg., ápice agudo a obtuso, lóbulos com 1-3 células, papila hialina no ápice; filídios com lóbulos bem desenvolvidos, ovalados a ovaladolanceolados, freqüentes, $150-200 \mu \mathrm{m}$ compr. $\times 90-110 \mu \mathrm{m}$ larg., ápice agudo a obtuso, lóbulos ovalados, 90-100 $\mu \mathrm{m}$ compr. $\times 70-80 \mu \mathrm{m}$ larg., alcançando $1 / 2$ a 2/3 do filídio, inflados, superfície lisa, quilha arqueada e denticulada, ápice com 2 dentes, separados por uma única célula, formando um sinus lunulado, primeiro dente redondo, projetado na direção do segundo dente e para a superfície ventral do lobo, menor ou do mesmo tamanho do segundo dente, papila hialina posicionada na base, segundo dente unicelular, redondo a triangular; margem dos filídios crenulada a denticulada; células dos filídios isodiamétrico-poligonais a oblongas, $10-13 \times 14-18 \mu \mathrm{m}$, sendo as das margens um pouco menores, superfície dorsal cônica com 1 papila central, superfície ventral lisa. Gemas discóides na surfície dorsal dos filídios. Androécio não observado. Ginoécio em ramos muito curtos, inovação ausente, brácteas em uma série, suberetas, semelhante aos filídios, porém maiores, lóbulos lanceolados, superfície das células e quilha iguais às dos filídios. Periantos obovados, inflados, 240-270 $\mu \mathrm{m}$ compr. $\times 120-180 \mu \mathrm{m}$ larg., 5 quilhas arredondadas, denticuladas, surperfície rugosa, células cônicas e unipapilosas. Esporófito não observado.

Distribuição geográfica: esta espécie ocorre em regiões tropicais e subtropicais da Flórida (EUA) e na Guiana Francesa (Schuster 1980; Pócs 1984; Pócs \& Lücking 1997). Primeira referência para o Brasil (IlkiuBorges \& Lisboa 2002).

Schuster (1980), reportou a dependência desta espécie por umidade elevada, o que restringe sua distribuição. Aphanolejeunea contractiloba assemelha-se a A. clavatopapillata (Steph.) E. Reiner (Reiner-Drehwald 1995). A principal diferença entre essas duas espécies está no lóbulo desenvolvido, pois A. clavatopapillata apresenta o primeiro dente alongado, com 2 células compr., direcionado para o ápice do filídio, enquanto que em $A$. contractiloba apresenta o primeiro dente unicelular, direcionado para o segundo dente e para a supefície ventral do lobo.

Material examinado: BRASIL. Pará: Melgaço, ECFPn: margem esquerda do Rio Curuá, mata de várzea, sobre tronco de Erisma sp., 8/XII/1997, A.L. Ilkiu-Borges et al. 1101 (MG).

2. Aphanolejeunea gracilis Jov.-Ast, Rev. Bryol. Lichénol. 16: 21. 1947.

Tipo. Guadeloupe. Sur Fougère, Cascade Vauchelet, 4.II.1936, Allorge \& Allorge (PC).

Fig. 2.

Gametófitos verde-pálidos, 2-4(-5)mm compr.× 0,5-0,7mm larg. Caulídio em secção transversal, 5 células epidérmicas circundando 1 célula medular; merófito ventral de 1 célula de largura. Filídios distantes a contíguos, dispostos obliquamente, dimórficos; filídios com lóbulos reduzidos, ligulados a elípticos ou ovalados, freqüentes, $150-170 \mu m$ compr. $\times 40-50 \mu m$ larg., ápice agudo a obtuso, lóbulos 1-3 células, papila hialina no ápice; filídios com lóbulos bem desenvolvidos, elíptico-ovalados a ovaladolanceolados, 250-400 $\mu \mathrm{m}$ compr.×60-90 $\mu \mathrm{m}$ larg., ápice agudo a obtuso, lóbulos ovalados a retangulares,

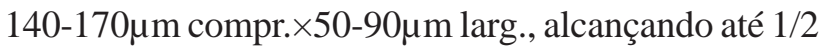
do filídio, inflados, superfície lisa, quilha levemente arqueada e lisa, ápice com 1 dente, unicelular, alongado a muito curto, papila hialina posicionada na base; margem dos filídios inteira a levemente crenulada; células dos filídios isodiamétrico-poligonais a oblongas, $20-40 \times 15-20 \mu \mathrm{m}$, sendo as das margens menores, superfície dorsal lisa, mamilosas nas margens, superfície ventral lisa. Gemas discóides na superfície dorsal dos filídios. Androécio terminal em ramos principais ou laterais, 1-3 pares de brácteas, brácteas masculinas grandes, semelhante aos filídios com lóbulos desenvolvidos. Ginoécio em ramos muito curtos, 1 inovação, brácteas em uma série, sub-eretas, semelhante aos filídios, porém maiores, lóbulos 

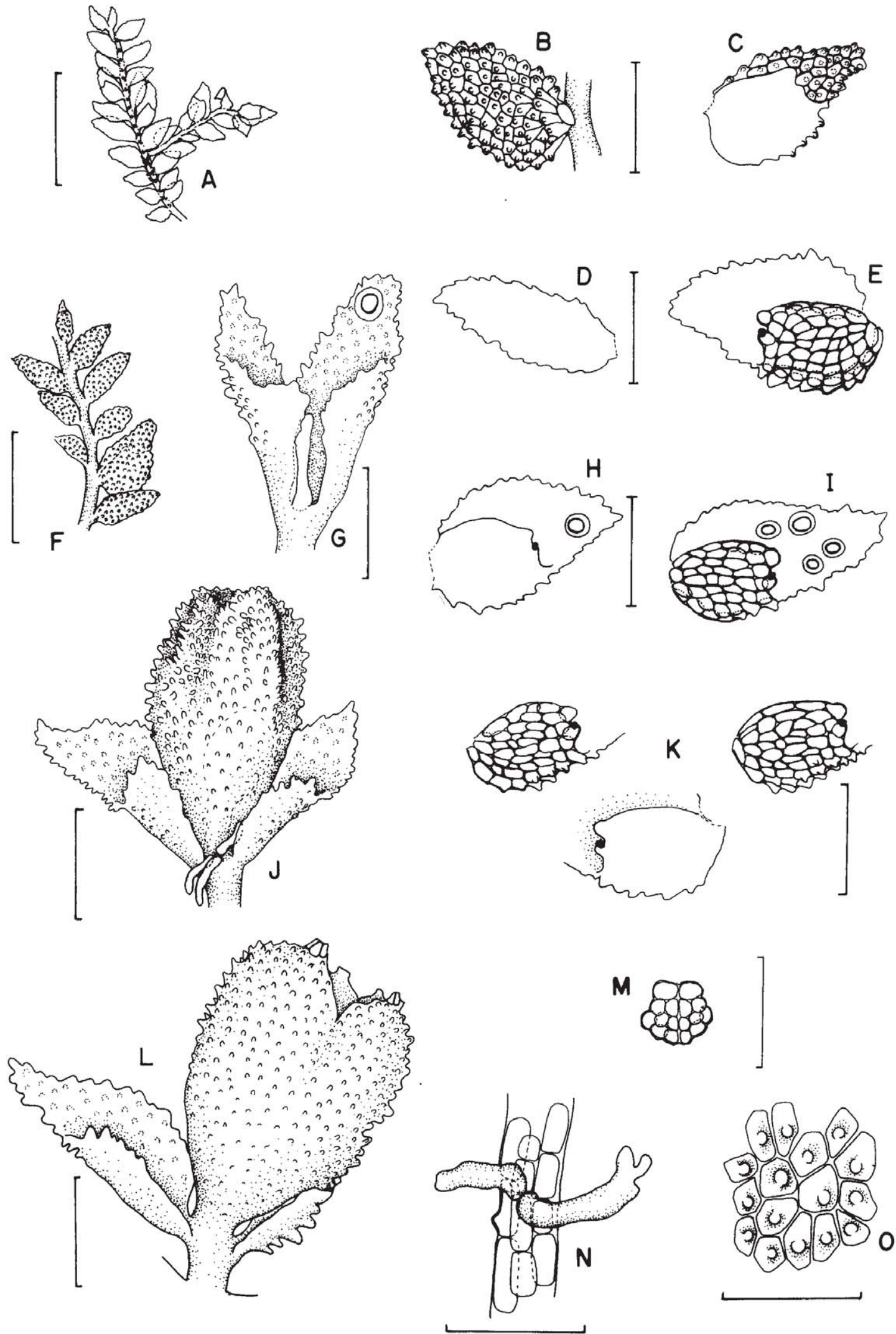

Figura 1. Aphanolejeunea contractiloba (A. Evans) R.M. Schust. (A-O) A. Hábito, vista ventral. B. Filídio, vista dorsal. C. Filídio. D. Filídio elobulado. E. Filídio com lóbulo em detalhe. F. Hábito, vista dorsal. G. Ginoécio. H-I. Filídios com gemas. J. Perianto. K. Lóbulos. L. Perianto rompido. M. Gema. N. Caulídio com rizóide. O. Células da região mediana do filídio (A.L. Ilkiu-Borges et al. 1101). Escalas: $A=1 \mathrm{~mm} ; \mathrm{F}=200 \mu \mathrm{m} ; \mathrm{B}-\mathrm{E}, \mathrm{G}-\mathrm{L}, \mathrm{M}=100 \mu \mathrm{m} ; \mathrm{N}, \mathrm{O}=50 \mu \mathrm{m}$. 

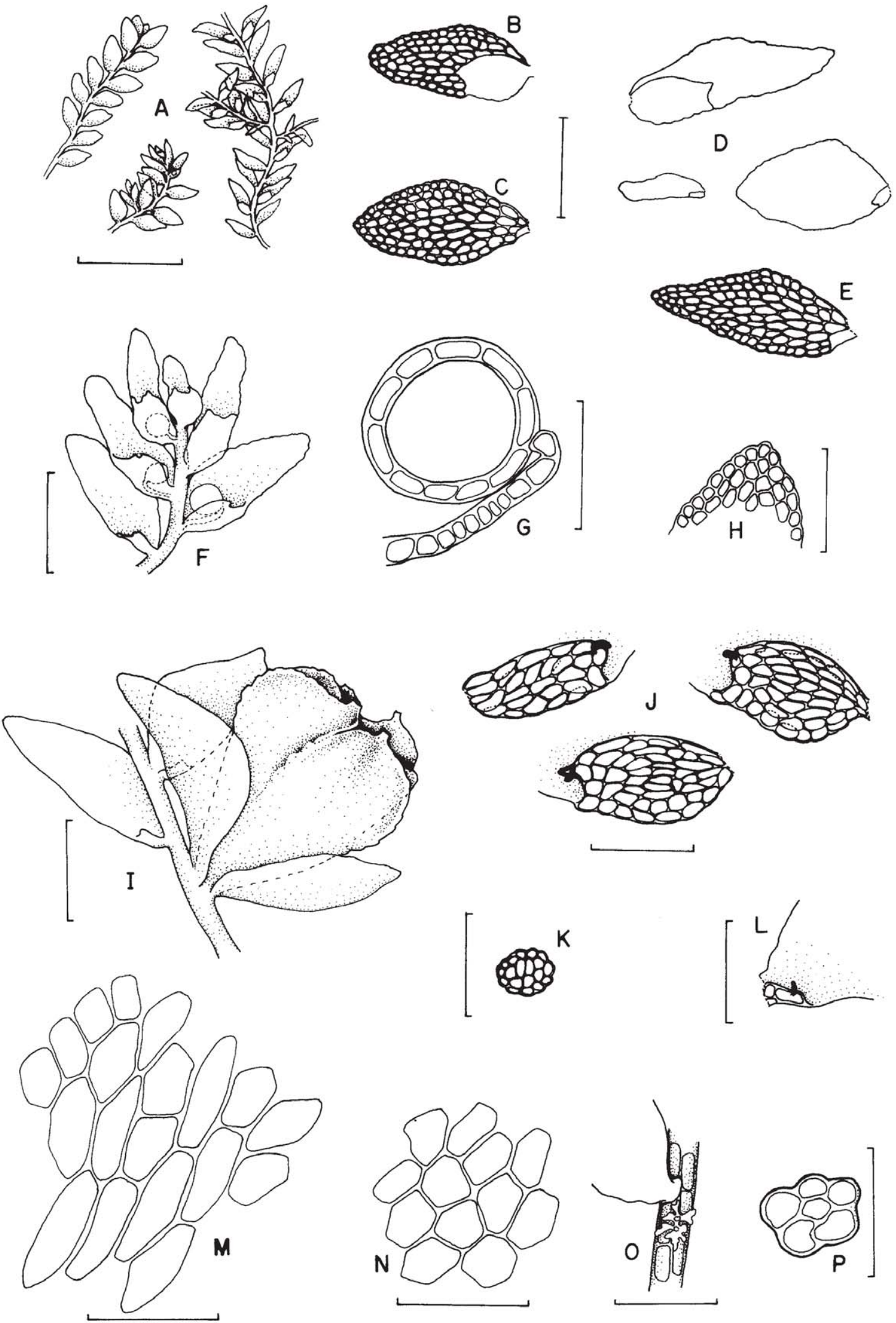

Figura 2. Aphanolejeunea gracilis Jov-Ast. (A-P) A. Hábitos, vista ventral. B-E. Filídios. F. Androécio. G. Anterídio. H. Detalhe do ápice do filídio. I. Perianto. J. Lóbulos. K. Gema. L. Lóbulo reduzido. M. Células da região basal do filídio. N. Células da região mediana do filídio. O. Caulídio com rizóides na base do filídio. P. Secção transversal do caulídio (A.L. Ilkiu-Borges et al. 1079). Escalas: A = 1mm;

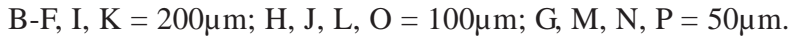


lanceolados, superfície das células e quilha iguais às dos filídios. Periantos obovados, inflados, 500 $\mathrm{m}$ compr. $\times 400 \mu m$ larg., 5 quilhas levemente aladas, crenuladas, superfície lisa, células lisas a levemente mamilosas. Esporófito não observado.

Distribuição geográfica: é citada para o Caribe, Colômbia, Costa Rica, El Salvador, Galápagos, Guadeloupe e Guiana Francesa (Pócs 1984). Primeira referência para o Brasil (Ilkiu-Borges \& Lisboa 2002).

Aphanolejeunea gracilis pode ser confundida com A. ephemeroides R.M. Schust. Entretanto esta última distingue-se pela superfície dorsal das células dos filídios que tendem a ser mamilosas, inclusive na parte central do lobo, e pelos lóbulos desenvolvidos que apresentam 2 dentes no ápice, sendo o primeiro dente falcado, com 2 células compr., justaposto ao segundo dente, de 1 célula compr. (descrição e ilustração: Schuster 1980). Aphanolejeunea gracilis apresenta células mamilosas apenas nas margens e somente 1 dente no ápice do lóbulo.

Material examinado: BRASIL. Pará: Melgaço, ECFPn: na margem direita do igarapé Curuazinho, inventário 11, várzea, sobre folha viva, 5/XI/1996, A.L. Ilkiu-Borges et al. 702 (MG); na margem esquerda do Rio Curuá, várzea, sobre folhas vivas e ramos de Eugenia sp., 29/XI/1997, A.L. Ilkiu-Borges et al. 874 (MG); idem, sobre folha de Aganisia sp. (Orchidaceae), 29/XI/1997, A.L. Ilkiu-Borges et al. 876 (MG); idem, terra firme, sobre folhas de Aspidosperma sp., 2/XII/1997, A.L. Ilkiu-Borges et al. 879 (MG); idem, sobre folhas vivas, 2/XII/1997, A.L. Ilkiu-Borges et al. 881 (MG); idem, 2/XII/1997, A.L. Ilkiu-Borges et al. 883 (MG); idem, sobre folhas de epífita, 8/XII/1997, A.L. Ilkiu-Borges et al. 1079 (MG); idem, sobre tronco de Steris sp., 8/XII/1997, A.L. Ilkiu-Borges et al. 1097 (MG); idem, sobre folhas de Erisma sp., 8/XII/1997, A.L. Ilkiu-Borges et al. 1101 (MG); idem, sobre tronco de Macrolobium sp., 8/XII/1997, A.L. Ilkiu-Borges et al. 1171 (MG); em mata de terra firme próximo a sede da ECFPn, solo argiloso, sobre tronco vivo (Leguminosae), 9/X/1993, R. Lisboa et al. 2506 (MG); na margem do igarapé Grande, várzea, sobre folhas vivas, 9/XI/1996, R. Lisboa et al. 6263 (MG).

3. Aphanolejeunea truncatifolia Horik., J. Sci. Hiroshima Univ., Ser. 3, Div. 2, 2: 284. 1934.

Tipo. Taiwan. Mt. Taiheizan, Prov. Taihoka, VIII/1932, Horikawa 11448 (HIRO).

Fig. 3, A-H.
Gametófitos verde-pálidos a amarelo-esverdeados, 1-2mm compr. $\times 0,2-0,3 m m$ larg. Caulídio em secção transversal, 5-7 células epidérmicas circundando 2 células medulares de tamanho menor; merófito ventral de 1-2 células de largura. Filídios distantes, suberetos, dimórficos; filídios com lóbulo reduzido, ligulados,

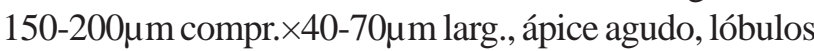
com 1-2 células, papila hialina no ápice; filídios com lóbulos desenvolvidos, ovalados a ovalado-lanceolados,

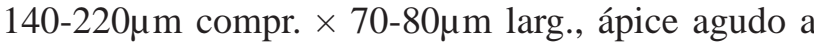
truncado, lóbulos ovalados, $100-120 \mu m$ compr. $\times$ 50-65 $\mathrm{mm}$ larg., alcançando 1/2 a 2/3 do filídio, inflados, superfície lisa, quilha arqueada, \pm lisa a denticulada, ápice com 2 dentes, primeiro dente 2 células compr., ereto, papila hialina posicionada na base, segundo dente unicelular, obtuso a triangular, às vezes obsoleto; margem dos filídios inteira a crenulada; células dos filídios isodiamétricas a alongadas, 10-16×19-25 $\mu \mathrm{m}$, sendo as das margens menores, superfície dorsal lisa no interior do filídio e geralmente mamilosa na margem, superfície ventral lisa. Gemas, androécio, ginoécio, perianto e esporófito não observados.

Distribuição geográfica: ocorre no sudeste da Ásia, em todo continente americano e na África Tropical (Pócs \& Lücking 1997). No Brasil, é referida para os Estados de PE e SP, como A. subdiaphana (Jov.-Ast.) Pócs (Yano 1995), e para o Estado do RJ, como A. diaphana (A. Evans) R.M. Schust. Primeira referência para o Estado do Pará (Ilkiu-Borges \& Lisboa 2002).

Aphanolejeunea truncatifolia tem como sinônimos A. diaphana e A. subdiaphana (Pócs \& Lücking 1997). Na ECFPn, esta espécie só ocorreu em mata de terra firme, sobre folha viva no sub-bosque. Aphanolejeunea truncatifolia assemelha-se a A. missionensis E. Reiner (Reiner-Drehwald 1995), entretanto esta última apresenta os lóbulos sempre reduzidos, células basais do lobo com até $60 \mathrm{~mm}$ compr., plantas mais robustas (500-810 $\mu$ m larg.) e filídios com 320-500 $\mathrm{mm}$ compr. Aphanolejeunea truncatifolia apresenta lóbulos desenvolvidos e reduzidos, células basais do lobo com até $30 \mu \mathrm{m}$ compr., gametófito com 200-300 $\mu$ m larg. e filídios com até $210 \mu m$ compr.

Material examinado: BRASIL. Pará: Melgaço, ECFPn: margem esquerda do Rio Curuá, mata de terra firme, sobre folhas de planta jovem no sub-bosque, 5/XII/1997, A.L. Ilkiu-Borges et al. 919 (MG).

4. Aphanolejeunea winkleri Morales \& A. Lücking, Nova Hedwigia, 60: 120. 1995.

Tipo. Costa Rica. Província Heredia, Finca La 
Selva, 50m, 18/I/1993, Morales, Dauphin \& Umana 2361 (G, USJ).

Fig. 3, I-R.

Gametófitos verde-pálidos, 1-2mm compr.× 0,2-0,3mm larg. Caulídio em secção transversal, 4-5 células epidérmicas circundando 1 célula medular de tamanho menor; merófito ventral de 1 célula de largura. Filídios distantes, sub-eretos a obliquamente dispostos, dimórficos; filídios com o lóbulo reduzido, ligulados a

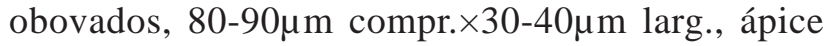
arredondado, lóbulo 1-5 células; filídios com lóbulos desenvolvidos, ovalados, $170-190 \mu \mathrm{m}$ compr. $\times 80-100 \mu \mathrm{m}$ larg., ápice arredondado, lóbulos ovalados, $110-130 \mu m$ compr. $\times 80-90 \mu \mathrm{m}$ larg., alcançando até $2 / 3$ do filídio, inflados, superfície lisa, quilha fortemente arqueada, inteira a levemente crenulada, ápice com 1 dente, 1-2 células compr., levemente falcado, papila hialina posicionada na base, na junção no lóbulo e lobo forma-se uma reentrância, marcada por 2 células protuberantes da superfície ventral do lobo; margem dos filídios inteira a levemente crenulada; células dos filídios isodiamétrica-poligonais a oblongas, $15-30 \times 8-15 \mu \mathrm{m}$, sendo as das margens menores, superfície dorsal e ventral lisas. Gemas discóides na superfície dorsal dos filídios. Androécio, ginoécio, perianto e esporófito não observados.

Distribuição geográfica: reportada para Costa Rica, Guiana Francesa e Suriname (Lücking 1997; Morales \& Lücking 1995). Primeira referência para o Brasil (Ilkiu-Borges \& Lisboa 2002).

Aphanolejeunea winkleri é facilmente distinguida das outras espécies do gênero pelo filídio por uma reentrância na junção do lóbulo e lobo, marcada por duas células protuberantes na superfície ventral do lobo, que junto com o dente apical, formam uma abertura arredondada no ápice do lóbulo. Segundo Morales \& Lücking (1995), essa reentrância na margem posterior do filídio com a presença das células protuberantes é uma característica única entre Aphanolejeunea.

Material examinado: BRASIL. Pará: Melgaço, ECFPn: margem esquerda do Rio Curuá, mata de terra firme, sobre folhas de planta jovem no sub-bosque, 5/XII/1997, A.L. Ilkiu-Borges et al. 919 (MG).

\section{Cololejeunea (Spruce) Schiffn.}

Cololejeunea é um gênero pantropical, que no Neotrópico está representado por cerca de 30 a 40 espécies em baixas elevações (Gradstein et al. 2001). Na ECFPn foram coletadas duas espécies deste gênero.
Chave artificial para as espécies de Cololejeunea

1. Filídios sem borda hialina (subgênero Cololejeunea) 1. C. obliqua

1. Filídios com borda hialina (subgênero Pedinolejeunea) 2. C. surinamensis

1. Cololejeunea obliqua (Nees \& Mont.) Schiffn., Bot. Jahrb. Syst. 23: 586. 1897.

Lejeunea obliqua Nees \& Mont., Ann. Sci. Nat. Bot., sér. 2, 19: 264. 1843. Tipo. Guiana Francesa. Cayenne, s.d., Leprieur s.n.

Fig. 4.

Gametófitos verde-pálidos, prostrados, 4-10mm compr.×1,3-1,5mm larg. Caulídio em secção transversal, 5 células epidérmicas circundando 1 célula medular de tamanho menor; merófito ventral de 2 células de largura. Filídios contíguos a sub-imbricados, obliquamente dispostos no caulídio, oblongos a ovalados, 550-750 $\mu \mathrm{m}$ compr. $\times 350-500 \mu \mathrm{m}$ larg., planos, ápice arredondado, margem inteira; lóbulos obovados, 220-280 $\mu$ m compr. $\times 120-170 \mu m$ larg., alcançam 1/3 do filídio, fortemente inflados na base, margem livre plana, superfície lisa, quilha arqueada, inteira, ápice com 2 dentes, primeiro dente, 2 células compr., papila hialina posicionada na base, segundo dente, 1 célula compr., triangular a arredondado, às vezes obsoleto; células do filídio, isodiamétricas a levemente alongadas, 15-30 $\mu \mathrm{m}$, unipapilosas próximo as margens, lisas da base a \pm metade do filídio, trigônios inconspícuos, 0-1 espessamento intercelular, cutícula lisa. Gemas discóides na superfície ventral dos filídios. Androécio terminais em ramos laterais, 3 séries de brácteas, brácteas menores que os filídios, ovaladas. Ginoécio em ramos muito curtos, 1 série de brácteas, ovaladolanceoladas, ápice agudo a obtuso, lóbulos oblongos, superfície das células e quilha iguais às dos filídios. Periantos obovados, inflados, $450-800 \mu \mathrm{m}$ compr. $\times 300-400 \mu m$ larg., 5 quilhas arredondadas, superfície papilosa. Esporófito como na tribo.

Distribuição geográfica: essa espécie está amplamente distribuída na região neotropical (Tixier 1985). No Brasil, é citada para os Estados do AM, PE, PR, SC e SP (Yano 1984a, 1995). Citada como C. scabrifolia (Gott.) Schiffn. para SP. Primeira referência para o Estado do Pará (Ilkiu-Borges \& Lisboa 2002).

Espécie epífita, segundo Tixier (1985). Na ECFPn, ocorre preferencialmente sobre folhas. São facilmente reconhecidas pelos filídios com superfície papilosa próximo às margens. Essa característica, também a 

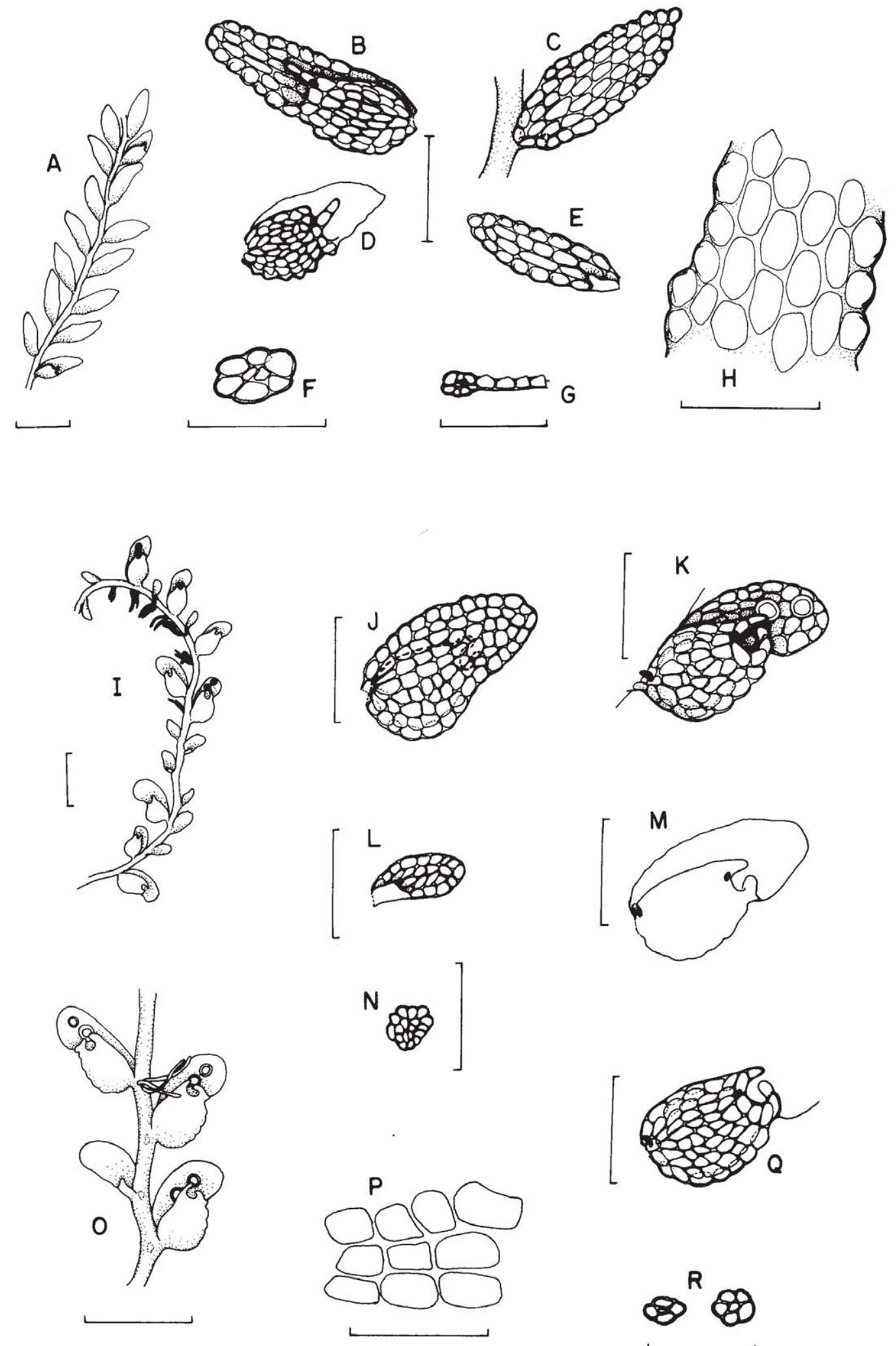

Figura 3. Aphanolejeunea truncatifolia Horik. (A-H) A. Hábito, vista ventral. B-E. Filídios. F-G. Secção transversal do caulídio. H. Células da região mediana do filídio (A.L. Ilkiu-Borges et al. 919). Aphanolejeunea winkleri Morales \& A. Lücking (I-R) I. Hábito, vista ventral. J. Filídio, vista ventral. K-M. Filídios. N. Gema. O. Detalhe do hábito. P. Células da região mediana do filídio. Q. Lóbulo.

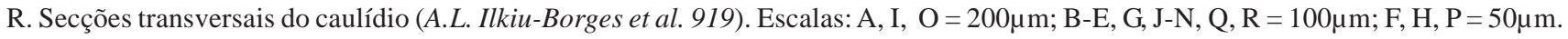



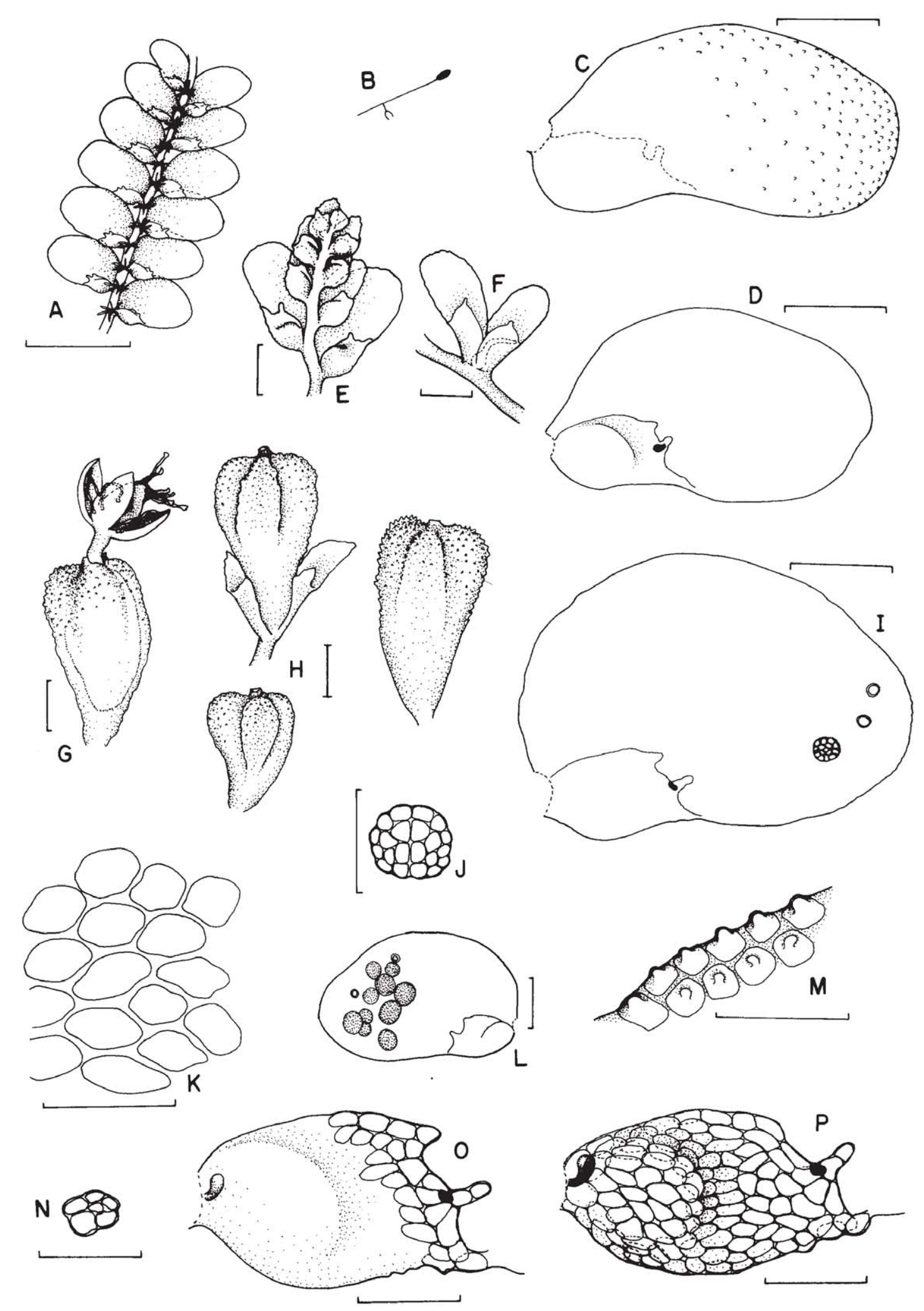

Figura 4. Cololejeunea obliqua (Nees \& Mont.) Schiffn. (A-P) A. Hábito, vista ventral. B. Esquema de planta fértil (•= androécio, $\mathrm{O}$ = ginoécio). C. Filídio, vista dorsal. D. Filídio, vista ventral. E. Androécio. F. Ginoécio. G. Perianto com esporófito. H. Periantos. I. Filídio com gemas. J. Gema. K. Células da região mediana do filídio. L. Filídio com gemas. M. Detalhe da margem do filídio. N. Secção transversal do caulídio. O. Lóbulo com os dois dentes bem desenvolvidos. P. Lóbulo com um dente bem desenvolvido e outro obsoleto

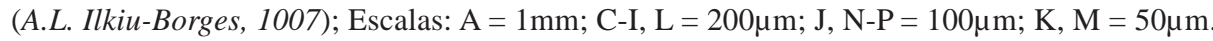


diferencia das outras espécies do subgênero Cololejeunea, na América do Sul (Tixier 1991).

Material examinado: BRASIL. Pará: Melgaço, ECFPn, margem esquerda do Rio Curuá, várzea, sobre folhas vivas de epífita (Pteridófita), 29/XI/1997, A.L. Ilkiu-Borges et al. 878 (MG); idem, terra firme, sobre folhas de Aspidosperma sp., 2/XII/1997, A.L. IlkiuBorges et al. 879 (MG); igarapé Laranjal, caminho para o laranjal, capoeira, sobre folha de palmeira, 7/XII/1997, A.L. Ilkiu-Borges 1007 (MG); margem do rio Curuá, várzea, sobre plântula no sub-bosque, 8/XII/1997, A.L. Ilkiu-Borges et al. 1040 (MG); idem, sobre folha de cipó, 8/XII/1997, A.L. Ilkiu-Borges et al. 1052; idem, sobre folhas, 8/XII/1997, A.L. IlkiuBorges et al. 1107 (MG); igarapé Retiro, inventário 12 , terra firme, sobre folha de palmeira, $1 / \mathrm{XI} / 1996$, R. Lisboa et al. 6033 (MG); idem, 1/XI/1996, R. Lisboa et al. 6035 (MG); idem, sobre folhas vivas, 1/XI/1996, R. Lisboa et al. 6040 (MG).

2. Cololejeunea surinamensis Tixier, Bradea 3: 42. 1980.

Tipo. Suriname. Bord de la Mana en venant d'Ouganado, 28.8.1952, R. Heim s.n. (PC).

Fig. 5.

Gametófitos verde-pálidos a esbranquiçados, muito delicados, prostrados, 2-4,5mm compr. $\times 1,6-2,7 \mathrm{~mm}$ larg. Caulídio em secção transversal, 6 células epidérmicas circundando 1 célula medular; merófito ventral de 2 células de largura. Filídios imbricados, obliquamente

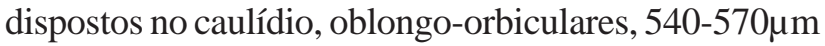
compr. $\times 420-460 \mu \mathrm{m}$ larg., planos, ápice amplamente arredondado, margem irregular, 50-70 $\mu$ m larg., formada por células hialinas, retangulares; lóbulos oblongos a obovados, $65-140 \mu \mathrm{m}$ compr. $\times 45-95 \mu \mathrm{m}$ larg., alcançam 1/8-1/4 do filídio, inflados na base, margem livre plana, superfície lisa, quilha levemente arqueada, inteira, primeiro dente conspícuo, 1-2 células compr., papila hialina posicionada na base (às vezes no ápice, se unicelular), segundo dente obsoleto; células do filídio isodiamétrica-poligonais, 21-34×29-45 $\mu$ m, trigônios conspícuos, 2-4 espessamentos intercelulares, cutícula reticulada. Gemas discóides na superfície ventral dos filídios. Androécio terminal em ramos muito curtos, 2-3 séries de brácteas, lobo e lóbulos do mesmo tamanho. Ginoécio em ramos muito curtos ou alongados e no ramo principal, 1 inovação, brácteas oblongas, ápice arredondado, lóbulos lanceolado-retangulares, com uma papila hialina no ápice. Periantos obovóides, achatado dorsi-ventralmente, $500-575 \mu \mathrm{m}$ compr. $\times 380-460 \mu \mathrm{m}$ larg., 2 quilhas laterais, aladas, arredondadas, ápice das quilhas contornado por células hialinas, margem inteira a irregular. Esporófito não observado.

Distribuição geográfica: essa espécie ocorre no Brasil e Suriname (Tixier 1980; Yano 1989). No Brasil é mencionada para os Estado do AM, MA, MG, MS, PR, RJ, SC e SP (Yano 1989). Primeira ocorrência para o Estado do Pará (Ilkiu-Borges \& Lisboa 2002).

A cutícula de Cololejeunea surinamensis foi descrita como papilosa (Tixier 1980), entretanto estudos realizados em microscópio eletrônico de varredura mostraram que a cutícula é reticulada. Essa característica foi confirmada pelo Dr. Tamas Pócs (comunicação pessoal, 1999). Esta espécie é reconhecida pelos filídios com uma borda hialina de células retangulares, lóbulos oblongos a obovados com o primeiro dente bastante visível, geralmente formado por 2 células de compr. É uma espécie epífila na ECFPn.

Material examinado: BRASIL. Pará: Melgaço, ECFPn, margem esquerda do Rio Curuá, terra firme, sobre folhas de epífita, 2/XII/1997, A.L. Ilkiu-Borges et al. 883 (MG); igarapé Retiro, caminho para o inventário 12, terra firme, sobre folhas vivas, 1/XI/1996, R. Lisboa et al. 6243 (MG); margem do igarapé Grande, várzea, sobre folhas vivas, 9/XI/1996, R. Lisboa et al. 6263 (MG).

III. Colura (Dum.) Dum.

Este é um gênero pantropical com muitos representantes (ca. 80 spp.) de acordo com Gradstein et al. (2001), mas somente cerca de 13 espécies estão distribuídas na América tropical. O gênero Colura, distingue-se das outras espécies da tribo pelos filídios, que apresentam a forma de um saco.

Apenas uma espécie de Colura foi coletada na ECFPn.

Colura tortifolia (Nees \& Mont.) Steph., Sp. Hepat. 5: 93. 1916.

Lejeunea tortifolia Nees \& Mont., Ann. Sci. Nat. Bot., ser. 2, 19: 265. 1843. Tipo. Guiana Francesa. S. loc., s.d., Leprieur s.n.

Fig. 6.

Gametófitos amarelo-pálidos, delicados, 3-6mm compr. Caulídio em secção transversal com 7 células epidérmicas circundando 3 células medulares de tamanho menor; merófito ventral de 2 células de largura. Filídios contíguos a distantes, esquarrosos, eretos, 600-1800 $\mu \mathrm{m}$ compr.×250-550 $\mathrm{mm}$ larg., lóbulo cilíndrico, formando um saco fechado com o lobo, ápice do filídio agudo a obtuso, \pm liso a crenulado, a abertura do saco é fechada por uma valva, 70-100 $\mu$ m compr., 

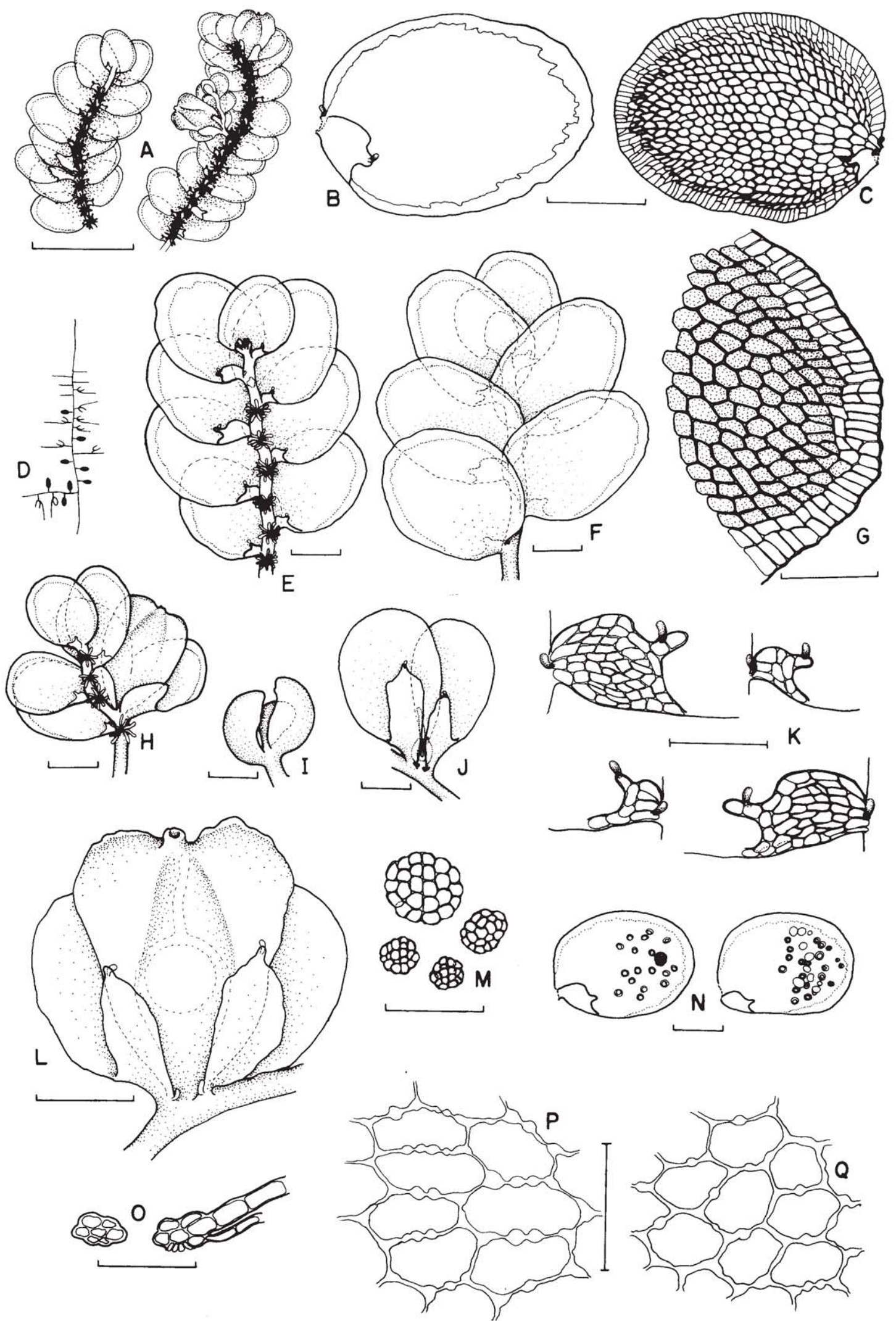

Figura 5. Cololejeunea surinamensis Tixier (A-Q) A. Hábitos, vista ventral. B-C. Filídios. D. Esquema de planta fértil (o = perianto, - = androécio, $\mathrm{O}$ = ginoécio). E. Detalhe do hábito, vista ventral. F. Detalhe do hábito, vista dorsal. G. Detalhe do ápice do filídio. H. Perianto com inovação. I. Androécio. J. Ginoécio. K. Lóbulos. L. Perianto em detalhe. M. Gemas. N. Filídios com gemas. O. Secções transversais do caulídio. P. Células da região basal do filídio. Q. Células da região mediana do filídio (A.L. Ilkiu-Borges et al. 883). Escalas: $\mathrm{A}=1 \mathrm{~mm}$; B-C, E-F, H-J, L, N = 200 $\mu \mathrm{m} ; \mathrm{G}, \mathrm{K}, \mathrm{M}, \mathrm{O}=100 \mu \mathrm{m} ; \mathrm{P}, \mathrm{Q}=50 \mu \mathrm{m}$. 
valva com borda hialina, base formada por 2 células alongadas, ligadas ao lóbulo por 3 células com uma papila hialina no ápice; células dos filídios isodiamétricas a oblongas, 25-50×15-20 $\mu$ m, superfície \pm lisa a mamilosa, trigônios conspícuos, 4-5 espessamentos intercelulares. Anfigastros bífidos, $210 \mu \mathrm{m}$ compr. $\times 100 \mu \mathrm{m}$ larg., lobos acuminados, divergentes. Gemas disciformes no ápice dos filídios. Androécio não observado. Ginoécio em ramos muito curtos, 1 série de brácteas, ovaladas, lóbulos lanceolados. Periantos sub-cilíndricos, 850-1000 $\mu \mathrm{m}$ compr. $\times 350-480 \mu$ m larg., 3 quilhas com bordas crenuladas por células cônicas. Esporófito não observado.

Distribuição geográfica: ocorre no Brasil, Colômbia, Costa Rica, Cuba, Equador, Guadalupe, Guiana, Guiana Francesa, Martinica, Panamá, Peru, Porto Rico, Suriname, Trinidad e Tobago (Jovet-Ast 1953). No Brasil foi mencionada para os Estados de PA (Lisboa \& Ilkiu-Borges 1995), e SP (Yano 1984a; 1995).

Material examinado: BRASIL. Pará: Melgaço, ECFPn, igarapé Laranjal, caminho para o laranjal, capoeira, sobre folhas de palmeira, 7/XII/1997, A.L. Ilkiu-Borges 1007 (MG); margem esquerda do Rio Curuá, terra firme, sobre plântula no sub-bosque, 8/XII/1997, A.L. Ilkiu-Borges et al. 1040 (MG); igarapé Grande, várzea, muito úmida, sobre sobre plântula viva e folhas, 17/I/1993, R. Lisboa 2310 (MG); igarapé Retiro, inventário 12, terra firme, sobre folha de palmeira, 1/XI/1996, $R$. Lisboa et al. 6033 (MG); igarapé Retiro, caminho para o inventário 12, terra firme, sobre folha de cipó, 1/XI/1996, $R$. Lisboa et al. 6049 (MG); margem do igarapé Grande, várzea, sobre folhas vivas, 9/XI/1996, R. Lisboa et al. 6263 (MG).

\section{Diplasiolejeunea (Spruce) Schiffn.}

Este é um gênero pantropical com cerca de 20 espécies na América tropical (Gradstein et al. 2001). Na ECFPn foi encontrada apenas uma espécie deste gênero.

Diplasiolejeunea brunnea Steph., Sp. Hepat. 5: 922. 1916.

Tipo. Guatemala. Coban, Türkheim, Levier 5826(G). Fig. 7.

Gametófitos amarelado-pálidos, prostrados, 3-8mm compr.×1,1-1,6mm larg. Caulídio em secção transversal, 7-8 células epidérmicas circundando 3 células medulares de tamanho menor; merófito ventral de 2 células de largura. Filídios imbricados, planos, oblongo-orbiculares, 650-800 $\mu \mathrm{m}$ compr. $\times 500-680 \mu \mathrm{m}$ larg., ápice amplamente arredondado, margem anterior maior que a margem posterior, ocelos espalhados no lobo, do mesmo tamanho das outras células, lóbulos oblongos, 300-350 $\mu \mathrm{m}$ compr. $\times 170-200 \mu \mathrm{m}$ larg., inflados, margem livre plana, primeiro dente 5 células de comprimento e duas células na base, papila hialina posicionada na base, segundo dente 2 células compr., curvado para dentro e para baixo, geralmente inconspícuo; células isodiamétricas na região mediana e próxima aos bordos, $15-20 \mu \mathrm{m}$, retangulares a oblongas na região basal, $10-15 \times 35-50 \mu \mathrm{m}$, lisas, trigônios pequenos a médios, 0 -3 espessamentos intercelulares. Anfigastros bífidos, 80-100 $\mu \mathrm{m}$ compr. $\times 450-550 \mu \mathrm{m}$ larg., lobos acuminados, amplamente divergentes. Androécio não observado. Ginoécio em ramos muito curtos, 1 série de brácteas, lanceoladas, ápice agudo a obtuso, lóbulos lanceolados, bractéola bífida, oblonga. Periantos sub-cilíndricos a obovóides, 900-1100 $\mu \mathrm{m}$ compr. e 490-500 $\mu \mathrm{m}$ larg., inflados, 5 quilhas achatadas, lisas. Esporófito não observado.

Distribuição geográfica: ocorre nas ilhas do Caribe, México, América Central, América do Sul, África e Oceania (Reyes 1982; Tixier 1985). No Brasil é mencionada para os Estados do AC (Vital \& Visnadi 1994), PA (Lisboa \& Ilkiu-Borges 1995), ES, RJ, RO, SC e SP (Yano 1984a; 1989; 1995).

Material examinado: BRASIL. Pará: Melgaço, ECFPn, margem esquerda do rio Curuá, várzea, sobre folhas vivas e ramos de Eugenia sp., 29/XI/1997, A.L. Ilkiu-Borges et al. 874 (MG); idem, sobre folhas vivas de epífita (Pteridófita), 29/XI/1997, A.L. Ilkiu-Borges et al. 878 (MG); idem, terra firme, sobre folhas vivas de Dodecastigma sp., 2/XII/1997, A.L. Ilkiu-Borges et al. 880 (MG); idem, sobre folhas vivas, 2/XII/1997, A.L. Ilkiu-Borges et al. 881 (MG); idem, sobre folhas vivas, 2/XII/1997, A.L. Ilkiu-Borges et al. 883 (MG); idem, várzea, sobre folhas vivas, 8/XII/1997, A.L. IlkiuBorges et al. 1134 (MG); igarapé Retiro, caminho para o inventário 12, terra firme, sobre folhas de palmeira, 1/XI/1996, R. Lisboa et al. 6033 (MG); baía de Caxiuanã, vegetação savanóide, periodicamente inundada, sobre tronco de murucizeiro, 4/XI/1996, R. Lisboa et al. 6062 (MG); margem do igarapé Grande, várzea, sobre folhas vivas, 9/XI/1996, R. Lisboa et al. 6263 (MG).

Como citado anteriormente, as espécies Aphanolejeunea truncatifolia, Cololejeunea obliqua e C. surinamensis foram coletadas na ECFPn pela primeira vez no Estado do Pará e 


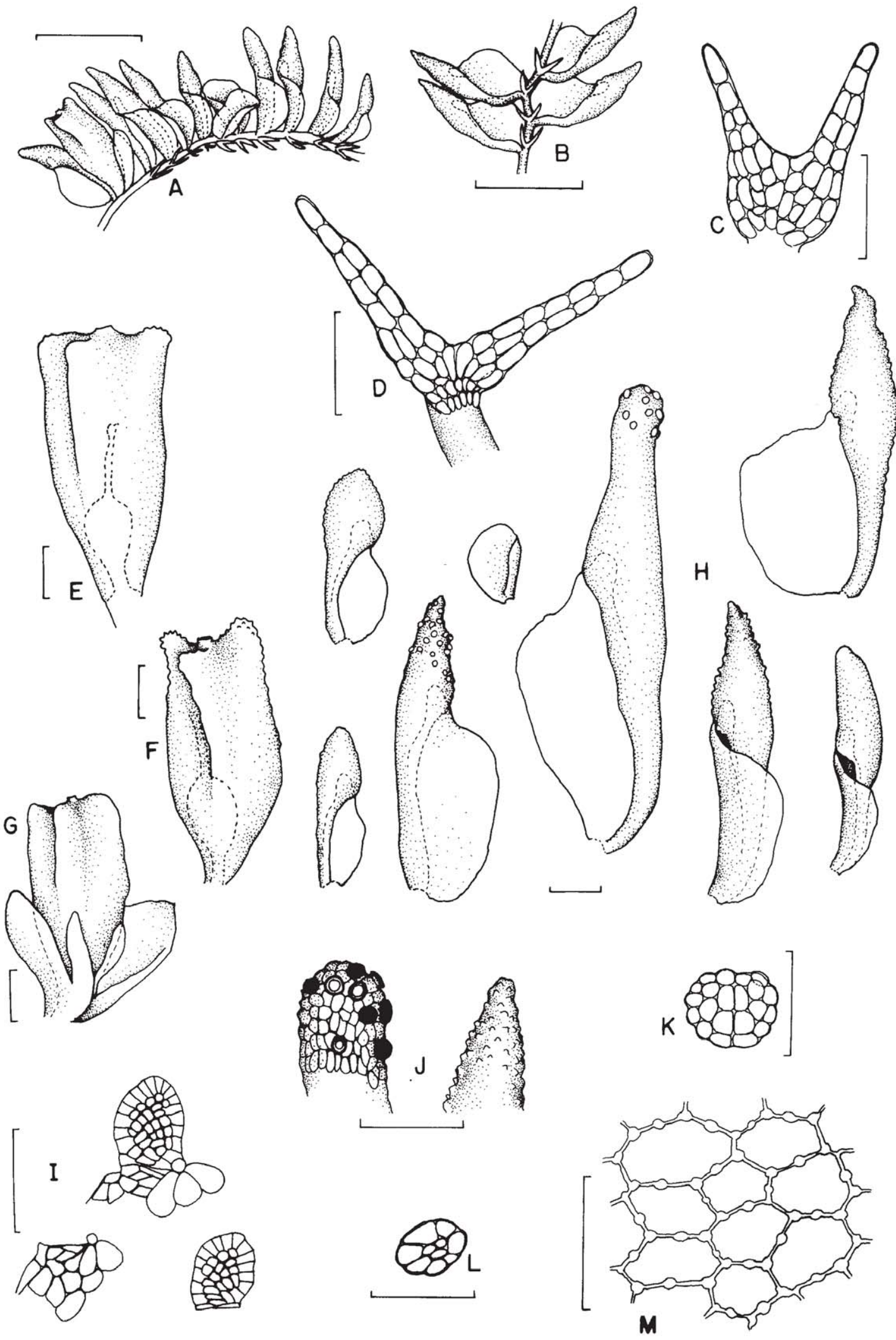

Figura 6. Colura tortifolia (Nees \& Mont.) Steph. (A-M) A. Hábito. B. Hábito, vista ventral. C-D. Anfigastros. E-G. Periantos. H. Oito exemplos de filídios. I. Detalhes da valva. J. Detalhe de ápices de filídios. K. Gema. L. Secção transversal do caulídio. M. Células da região

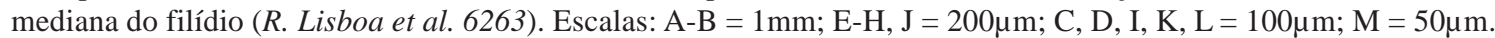



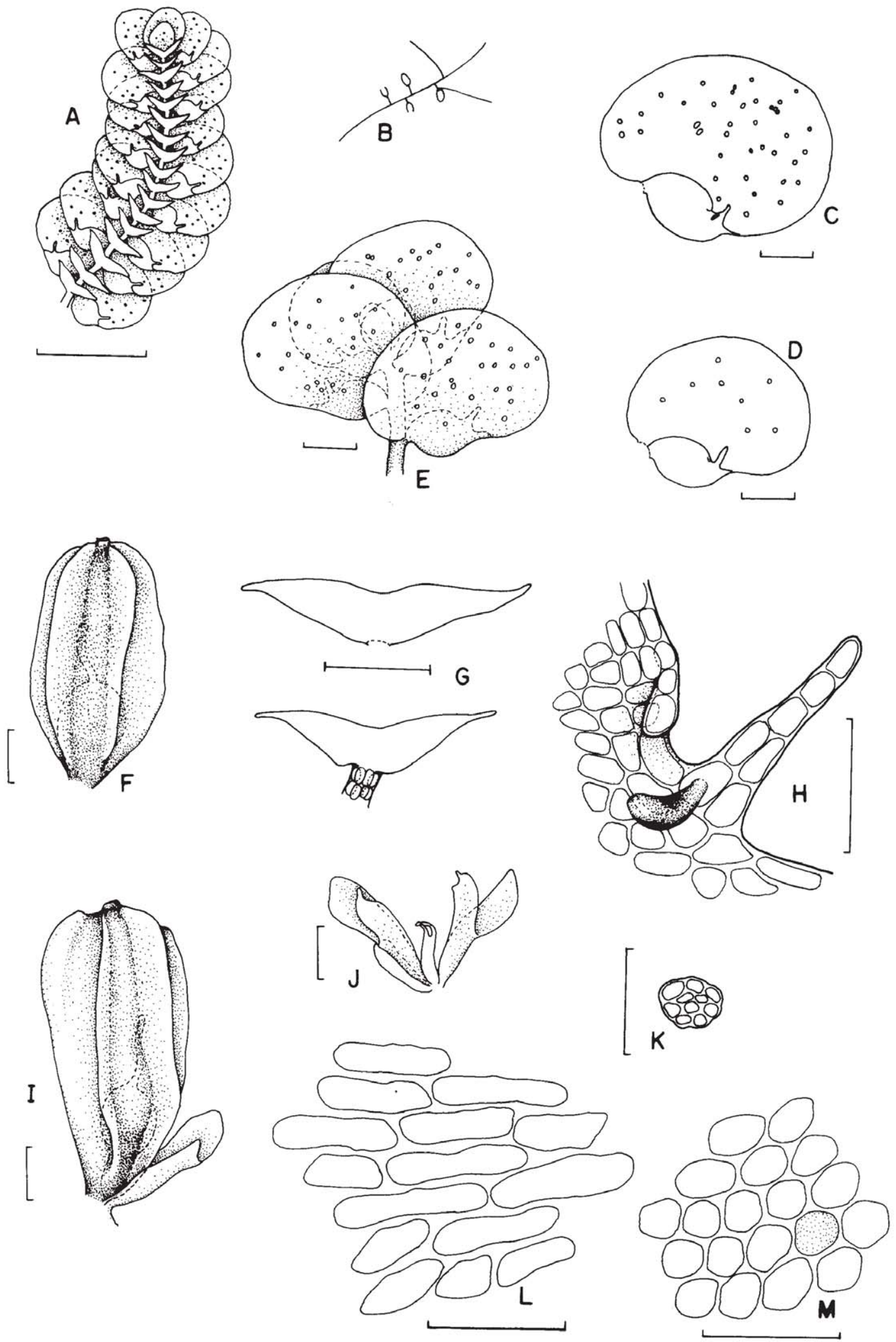

Figura 7. Diplasiolejeunea brunnea Steph. (A-M) A. Hábito, vista ventral. B. Esquema de planta fértil ( $0=$ perianto, $\bigcirc=$ ginoécio). C-D. Filídios com ocelos destacados. E. Hábito, vista dorsal. F. Perianto. G. Anfigastro. H. Detalhe interno do ápice do lóbulo e papila hialina. I. Perianto. J. Ginoécio. K. Secção transversal do caulídio. L. Células da região basal do filídio. M. Células da região mediana do filídio (R. Lisboa et al. 6033). Escalas: A = 1mm; C-G, I-J = 200 $\mu \mathrm{m} ; \mathrm{K}=100 \mu \mathrm{m} ; \mathrm{H}, \mathrm{L}-\mathrm{M}=50 \mu \mathrm{m}$. 
Aphanolejeunea contractiloba, A. gracilis e A. winkleri, no Brasil. Entretanto, foram citadas como novas ocorrências em uma lista de espécies de Lejeuneaceae de Caxiuanã por Ilkiu-Borges \& Lisboa (2002).

As espécies Aphanolejeunea contractiloba, A. truncatifolia e A. winkleri foram coletadas apenas uma vez na ECFPn, sendo consideradas de rara ocorrência, mas esse resultado pode modificar-se com uma amostragem maior na área da ECFPn.

Na Tabela 1 verifica-se que 83,33\% dos espécimes coletados ocorreram sobre folhas, enquanto apenas $16,66 \%$ sobre tronco de árvore viva. Foi observado que na ECFPn, a maior quantidade e diversidade de espécies epífilas foram coletadas sobre folhas de palmeira em sub-bosque, sendo registradas até 12 espécies por folha.

Tabela 1. Relação entre número de ocorrências e tipo de substrato das espécies de Cololejeuneae coletadas na área da Estação Científica Ferreira Penna.

\begin{tabular}{lrcc}
\hline \multirow{2}{*}{ Espécie } & \multirow{2}{*}{$\begin{array}{c}\text { Número de } \\
\text { ocorrências }\end{array}$} & \multicolumn{2}{c}{ Espécies } \\
\cline { 3 - 4 } & & Corticícola & Epífila \\
\hline Aphanolejeunea contractiloba & 1 & 1 & - \\
Aphanolejeunea gracilis & 12 & 3 & 9 \\
Aphanolejeunea truncatifolia & 1 & - & 1 \\
Aphanolejeunea winkleri & 1 & - & 1 \\
Cololejeunea obliqua & 9 & 1 & 8 \\
Cololejeunea surinamensis & 3 & - & 3 \\
Colura tortifolia & 6 & 1 & 5 \\
Diplasiolejeunea brunnea & 9 & 1 & 8 \\
Total & 42 & 7 & 35 \\
\hline
\end{tabular}

Na Tabela 2 observa-se que 54,76\% das espécies ocorreram em mata de Terra Firme, seguida por 38,09\% em mata de Várzea. Na vegetação savanóide, ocorreram apenas $4,76 \%$ das espécies e em capoeira ou mata secundária, ocorreram somente 2,38\%. Assim, conclui-se que na ECFPn os ecossistemas com maior diversidade e quantidade de espécies são ambientes de mata primária. Observa-se que a preservação das florestas tropicais primárias é essencial para o salvamento de comunidades de briófitas que ocorrem principalmente ou exclusivamente neste tipo de ecossitema. Assim como é fundamental o estudo intenso de áreas preservadas, como a ECFPn, e das que tendem a desaparecer com o crescimento demográfico e exploração para fins produtivos e econômicos.
Tabela 2. Relação entre número de ocorrência e tipo de ecossistema onde foram coletadas as espécies de Cololejeuneae na área da Estação Científica Ferreira Penna. MV - mata de várzea; MF mata de terra firme; VS - vegetação savanóide; MC - mata de capoeira.

\begin{tabular}{lcccr}
\hline Espécie & MV & MF & VS & MC \\
\hline Aphanolejeunea contractiloba & 1 & - & - & - \\
Aphanolejeunea gracilis & 4 & 8 & - & - \\
Aphanolejeunea truncatifolia & - & 1 & - & - \\
Aphanolejeunea winkleri & - & 1 & - & - \\
Cololejeunea obliqua & 4 & 4 & 1 & - \\
Cololejeunea surinamensis & 1 & 2 & - & - \\
Colura tortifolia & 2 & 3 & - & 1 \\
Diplasiolejeunea brunnea & 4 & 4 & 1 & - \\
Total & 16 & 23 & 2 & 1 \\
\hline
\end{tabular}

Todas as amostras de epífilas coletadas na ECFPn ocorreram nos ecossistemas de terra firme, várzea e capoeira, ressaltando que esta é uma área de capoeira alta, em avançado estágio de regeneração, circundada por mata primária. Nenhuma amostra epífila foi registrada na área de vegetação savanóide. Estudos indicam que as briófitas epífilas são mais comuns no sub-bosque de florestas, do que na copa das árvores (A. Lücking, comunicação pessoal, 1998). Essas parecem ser epífitas de sombra e são particularmente vulneráveis a distúrbios e destruição das florestas, estando entre as primeiras briófitas a desaparecer quando a cobertura das florestas é aberta (Gradstein 1992; 1997).

Assim como estas oito espécies, muitas outras ainda podem ser encontradas à medida que se intensifiquem as coletas e estudo de material nos demais municípios paraenses, dos quais, como ressaltou Lisboa (1994), a imensa maioria nunca foi visitada por botânicos e especialistas em briófitas. Isso vem sendo confirmado com trabalhos recentes como o de Lisboa \& Ilkiu-Borges (1997), que referem pela primeira vez 11 espécies de musgos para o Estado do Pará e duas novas para o Brasil.

\section{Referências bibliográficas}

Gradstein, S.R. 1992. The vanishing tropical rain forest as an environment for bryophytes and lichens. Pp. 234-258. In: J.W. Bates \& A.M. Farmer (eds.). Bryophytes and Lichens in a Changing Enviroment. Oxford, Clarendon Press.

Gradstein, S.R. 1997. The taxonomic diversity of epiphyllous bryophytes. Abstracta Botanica 21: 15-19.

Gradstein, S.R.; Churchill, S.P. \& Salazar-Allen, N. 2001. Guide to the bryophytes of Tropical America. Memoirs of the New York Botanical Garden 86: 1-577. 
Ilkiu-Borges, A.L. \& Lisboa, R.C.L. 2002. Lejeuneaceae (Hepaticae). Pp. 399-419. In: P.L.B. Lisboa (org.). Caxiuanã: populações, meio físico e diversidade biológica. Belém, Museu Paraense Emílio Goeldi.

Jovet-Ast, S. 1953. Le genre Colura. Hépatiques. Lejeuneaceae, Diplasiae. Revue Bryollogique et Lichénologique 22: 206-312.

Lisboa, R.C.L. 1993. Musgos Acrocárpicos do Estado de Rondônia. Belém, Museu Paraense Emílio Goeldi.

Lisboa, R.C.L. 1994. Adições à brioflora do Estado do Pará. Boletim do Museu Paraense Emílio Goeldi, sér. Bot. 10(1): 15-42.

Lisboa, R.C.L. \& Ilkiu-Borges, A.L. 1995. Diversidade das Briófitas de Belém (PA) e seu potencial como indicadoras de poluição. Boletim do Museu Paraense Emílio Goeldi, sér. Bot. 11(2): 199-225.

Lisboa, R.C.L. \& Ilkiu-Borges, A.L. 1997. Novas Ocorrências de Bryophyta (Musgos) para o estado do Pará, Brasil. Acta Amazonica 27(2): 81-102.

Lücking, A. 1997. Diversity and distribuition of epiphyllous bryophytes in a tropical rainforest in Costa Rica. Abstracta Botanica 21(1): 79-87.

Morales, Z.M.I. \& Lücking, A. 1995. Aphanolejeunea winkleri Morales \& A. Lücking, a new species of Lejeuneaceae (Hepaticae, Cololejeuneoideae) from Costa Rica. Nova Hedwigia 60: 119-124.

Pócs, T. 1984. Present knowledge on Aphanolejeunea Evans. The Journal of Hattori Botanical Laboratory 55: 307-313.

Pócs, T. \& Lücking, A. 1997. The genus Aphanolejeunea A.Evans in the Guianas. Haussknechtia, Beiheft 7: 26-27.
Reiner-Drehwald, M.E. 1995. Las Lejeuneaceae (Hepaticae) de Misiones, Argentina. IV. Aphanolejeunea. Tropical Bryology 10: 29-39.

Reyes, D.M. 1982. El género Diplasiolejeunea en Cuba. Acta Botanica Academiae Scientiarum Hungaricae 28: 145-180.

Schuster, R.M. 1980. The Hepaticae and Anthocerothae of North America. East of the Hundredth Meridian. 4. New York, Columbia University Press.

Tixier, P. 1980. Contribution à la connaissance a l'etude du genre Cololejeunea (Lejeuneaceae). IX. Espèces nouvelles du suos genre Pedinolejeunea (Ben.) Mizutani en région néotropicale. Bradea 3(6): 35-44.

Tixier, P. 1985. Contribution à la connaissance des Cololejeunoideae. Hirschberg: Strauss \& Cramer 27. 439p.

Tixier, P. 1991. Bryophyta exotica- 9. Quelques Lejeuneaceae (Hépatiques) nouvelles pour L’Amérique du Sud. Candollea 46: 267-302.

Vital, D.M. \& Visnadi, S.R. 1994. Bryophytes of Rio Branco Municipality, Acre, Brazil. Tropical Bryology 9: 69-74.

Yano, O. 1984a. Checklist of Brazilian Liverworts and Hornworts. The Journal of Hattori Botanical Laboratory 56: 481-548.

Yano, O. 1984b. Briófitas. In: O. Fidalgo \& V.L.R Bononi. (Coords.). Técnicas de coleta, preservação e herborização de material botânico. São Paulo: Instituto de Botância. 62p. (Manual, 4).

Yano, O. 1989. An additional Checklist of Brazilian Bryophytes. The Journal of Hattori Botanical Laboratory 66: 371-434.

Yano, O. 1995. A New Additional Checklist of Brazilian Bryophytes. The Journal of Hattori Botanical Laboratory 78: 137-182. 